\title{
Effect of Calcium Additions on Creep Properties of a Die-Cast AM50 Magnesium Alloy
}

\author{
Daigo Itoh*1 ${ }^{* 1}$ Yoshihiro Terada*2 and Tatsuo Sato \\ Department of Metallurgy and Ceramics Science, Tokyo Institute of Technology, Tokyo 152-8552, Japan
}

Tensile creep tests have been carried out for the die-cast AM50 $+x \mathrm{Ca}(x=0.47,0.95$ and 1.72 mass pct $)$ alloys in the temperatures between 423 and $523 \mathrm{~K}$ to elucidate the effect of calcium additions on creep properties for the AM50 alloy. The creep curve for the AM50 $+x$ Ca alloys is characterized by a minimum in the creep rate followed by an extended accelerating stage, and the decrease in creep rate during transient stage becomes pronounced with calcium concentration. The creep strengthening by calcium addition is emphasized at lower stresses and lower temperatures, resulting in the positive dependence of creep parameters, $n$ and $Q_{\mathrm{c}}$, against calcium concentration. It is found that the eutectic intermetallic phase covering the primary $\alpha$ grains detected in the AM50 $+x$ Ca alloys prevents the dislocation annihilation at grain boundaries. The creep strengthening by the addition of calcium results from both the solid solution strengthening of the $\alpha$ matrix by solute calcium and the retardation of dislocation annihilation attributed to the eutectic intermetallic phase. [doi:10.2320/matertrans.MAW200830]

(Received May 2, 2008; Accepted June 13, 2008; Published July 30, 2008)

Keywords: magnesium alloy, die-cast, creep parameter, dislocation substructure

\section{Introduction}

Lightweight magnesium alloys have evoked an interest in the automotive industry for improving fuel efficiency through vehicle mass reduction in the past decade. ${ }^{1-3)}$ The use of the alloys for automotive applications is currently restricted to relatively low-temperature components. ${ }^{4)}$ The additional substantial increase of magnesium alloys is achieved by utilizing the alloys for high-temperature powertrain components. ${ }^{5,6)}$ Creep strength is a major requirement for the magnesium alloys to replace the powertrain components that are currently made of cast aluminum alloys or cast iron. ${ }^{7-11)}$

Die-casting is a dominant processing route to produce magnesium components due to its high productivity of complex near net shape parts. ${ }^{12,13)}$ The AM (Mg-Al-Mn) series alloys are the most commonly used magnesium alloys in automobiles because of a good combination of mechanical properties, corrosion resistance, and die-castability. ${ }^{1)}$ The creep properties of the AM50 alloy produced by die-casting were extensively investigated at temperatures above $423 \mathrm{~K}$ in our previous study. ${ }^{14)}$ The rate-controlling process of the alloy has been demonstrated as a dislocation climb from the results of creep curves and creep parameters.

The creep strength of die-cast $\mathrm{Mg}$-Al alloys has been improved by the single or combined additions ${ }^{15}$ of silicon, ${ }^{16,17)}$ strontium ${ }^{18)}$ and calcium. ${ }^{19-22)}$ Among the alloying elements described above, calcium is both a cost effective and lighter alternative to rare-earth elements for improving high-temperature creep strength of $\mathrm{Mg}$-Al alloys. ${ }^{23-27)}$ Phase equilibria $^{28,29)}$ and liquid projections ${ }^{30)}$ in the $\mathrm{Mg}-\mathrm{Al}-\mathrm{Ca}$ ternary system have been clarified by experimental methods and via thermodynamic modeling with particular emphasis on the Mg-rich corner. The aim of the present study is to elucidate the effect of calcium additions on creep properties

\footnotetext{
${ }^{* 1}$ Graduate Student, Tokyo Institute of Technology

${ }^{* 2}$ Corresponding author, E-mail: terada@numse.nagoya-u.ac.jp. Present address: Department of Materials, Physics and Energy Engineering, Nagoya University, Nagoya 464-8603, Japan
}

for the AM50 die-cast alloy in the temperatures above $423 \mathrm{~K}$.

The microstructure of the AM50 alloy produced by diecasting consists of the $\beta\left(\mathrm{Mg}_{17} \mathrm{Al}_{12}\right)$ phase in the matrix of the $\alpha$ magnesium solid solution. ${ }^{14,31)}$ On the contrary, the formation of $\beta$ phase is completely suppressed and the primary $\alpha$ grains are surrounded by an eutectic intermetallic phase when the calcium is added into AM50 alloy. ${ }^{15,32,33)}$ In this study, the role of the eutectic intermetallic phase on dislocation substructure is also investigated through the TEM observation. The coverage ratio of $\alpha$ grains by the eutectic intermetallic phase increases with the additive concentration of calcium for $\mathrm{Mg}$-Al alloys. ${ }^{34,35)}$ It has been demonstrated for the AM50 die-cast alloy that by the addition of 1.72 mass pct of calcium the primary $\alpha$ grains are almost covered by the eutectic intermetallic phase with the coverage ratio of 0.98 while the average diameter of $\alpha$ grains remains unchanged at around $7 \mu \mathrm{m} .^{36)}$

\section{Experimental}

The three kinds of $\mathrm{AM} 50+x \mathrm{Ca}(x=0.47,0.95$ and 1.72 mass pct) alloys were produced using a cold chamber die-casting machine, where the chemical composition of the alloys is listed in Table 1. The experimental alloys are hereafter referred by their calcium content. The melt temperature was controlled at $993 \mathrm{~K}$, and the die-surface temperature was maintained constant at $473 \mathrm{~K}$. The materials were obtained in the form of plates $150 \mathrm{~mm}$ in length, $70 \mathrm{~mm}$ in width, and with thickness that varied in steps from 1 to $3 \mathrm{~mm}$. Specimens for the creep tests with a gage length of $28 \mathrm{~mm}$ and a rectangular cross-section of $6 \times 3 \mathrm{~mm}$ were taken from the $3 \mathrm{~mm}$ thickness sections of the castings. The axes of the specimens were parallel to the $70 \mathrm{~mm}$ direction of the plates.

Tensile creep tests were carried out in air, using lever arm creep machines in the temperatures between 423 and $523 \mathrm{~K}$, under initial applied stresses that varied between 30 and $120 \mathrm{MPa}$. Two chromel-almel thermocouples were attached along the gage length of the specimen. Before loading, the specimens were held at test temperatures for at least 1 hour in 
Table 1 Chemical composition of the AM50 + Ca die-cast alloys used in this study (in mass pet).

\begin{tabular}{ccccc}
\hline Alloy code & $\mathrm{Al}$ & $\mathrm{Mn}$ & $\mathrm{Ca}$ & $\mathrm{Mg}$ \\
\hline AM50 & 5.42 & 0.28 & - & bal. \\
$0.47 \mathrm{Ca}$ & 4.90 & 0.28 & 0.47 & bal. \\
$0.95 \mathrm{Ca}$ & 5.20 & 0.22 & 0.95 & bal. \\
$1.72 \mathrm{Ca}$ & 4.98 & 0.29 & 1.72 & bal. \\
\hline
\end{tabular}

the creep furnace, to stabilize the temperatures of the specimens. The accuracy of the temperature and the temperature gradient along the gage length were controlled so that they remained within $2 \mathrm{~K}$ during the test. The elongation of the specimen was measured by an extensometer attached to ridges at both ends of the gage portion, where the displacement of the extensometer heads was continuously recorded by linear variable differential transformers (LVDTs).

A part of the creep tests were rapidly cooled under load by using compressed air to preserve the dislocation substructure, which was observed using a Jeol transmission electron microscope (TEM) operated at an accelerating voltage of $200 \mathrm{kV}$. Thin foils were cut from the materials and machined to discs with a diameter of $3 \mathrm{~mm}$. After mechanical grinding down to approximately $150 \mu \mathrm{m}$, the discs were polished electrolytically in a standard twin-jet polisher using a solution of methanol and perchloric acid in a ratio of $0.9: 0.1$. The polishing conditions were set to $243 \mathrm{~K}$ and $25 \mathrm{~V}$, giving a polishing-current of approximately $0.1 \mathrm{~A}$. Compositional analysis was conducted in the scanning electron microscope (SEM) equipped with an EDS system operating at $20 \mathrm{kV}$ by using the specimens polished through the standard metallographic procedure.

\section{Results and Discussion}

\subsection{The shape of the creep curves}

The creep curves for the AM50 $+x \mathrm{Ca}(x=0.47,0.95$ and 1.72 mass pct) alloys tested at $473 \mathrm{~K}$ under the stress of $60 \mathrm{MPa}$ are shown in Fig. 1, together with the result for the AM50 alloy. The calcium added specimens exhibit improved creep resistance compared to the AM50 specimen. Less creep strain is accumulated during creep with increasing calcium concentration. It is noted that the elongation to creep rupture for the AM50 alloy is 20.3 pct, ${ }^{37)}$ and it continuously decreases with increasing calcium concentration to the value of 4.4 pct for the $1.72 \mathrm{Ca}$ alloy.

The creep rate, obtained from the creep curve by differentiating the creep strain with respect to time, is plotted against time in double logarithmic coordinates in Fig. 2. After a transient creep region, the curve shows a minimum in the creep rate followed by a region with increasing creep rate; a distinct steady-state region with constant creep rate is not identified for each alloy. The minimum creep rate rather than the steady-state creep region is identified in the tensile creep tests for other die-cast magnesium alloys; AS21, ${ }^{38)}$ AZ91 ${ }^{38-40)}$ and MRI153. ${ }^{41)}$ The minimum creep rate appears after approximately $20 \mathrm{pct}$ of the time to rupture for the AM50 alloy, indicating that the creep of the alloy is predominantly occupied by the accelerating creep region

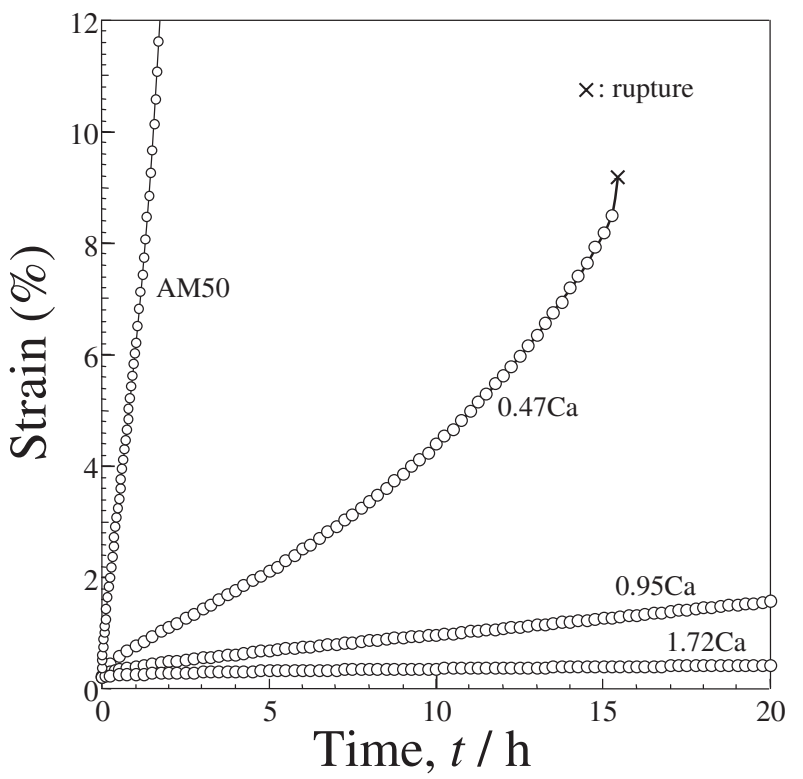

Fig. 1 Creep curves at $473 \mathrm{~K}$ under the stress of $60 \mathrm{MPa}$ for the $\mathrm{AM} 50+x \mathrm{Ca}$ die-cast alloys.

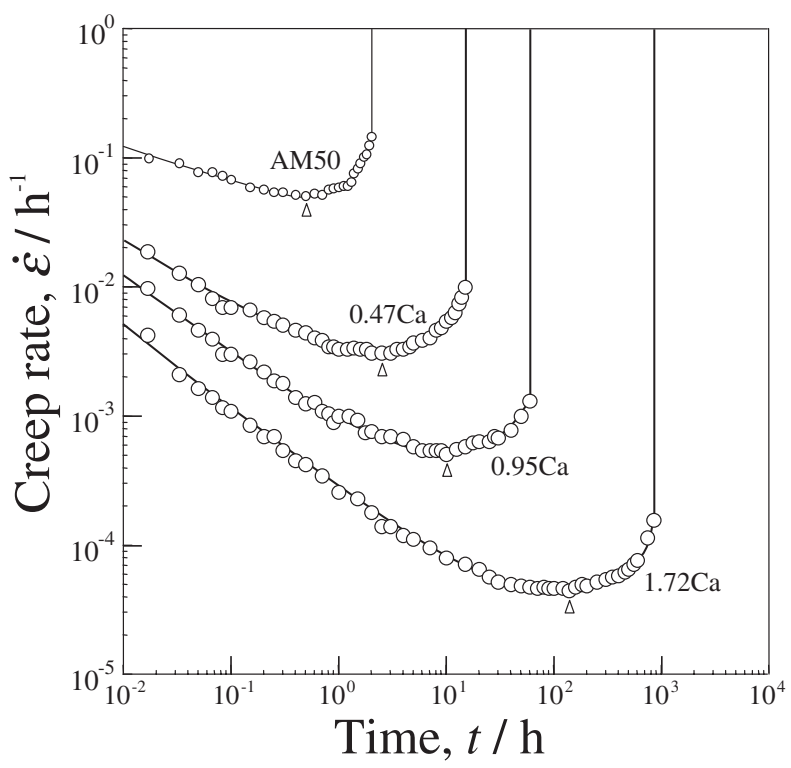

Fig. 2 Creep rate vs. time curves at $473 \mathrm{~K}$ under the stress of $60 \mathrm{MPa}$ for the $\mathrm{AM} 50+x \mathrm{Ca}$ die-cast alloys. Minimum creep rates are indicated by arrows.

rather than the transient creep region. The ratio of the transient creep duration to the rupture life remains unchanged at around 20 pct irrespective of calcium concentration for the $\mathrm{AM} 50+x \mathrm{Ca}$ alloys.

The decrease in creep rate during transient stage becomes pronounced with increasing calcium concentration. For the AM50 alloy, the creep rate after $10^{-2} \mathrm{~h}(36 \mathrm{~s})$ is $1.2 \times$ $10^{-1} \mathrm{~h}^{-1}$ and the minimum creep rate is $6.3 \times 10^{-2} \mathrm{~h}^{-1}$. The creep rate is reduced to about $1 / 2$ during the transient stage for the alloy at the creep condition of $473 \mathrm{~K}-60 \mathrm{MPa}$. On the contrary, the reduction ratio of creep rate is emphasized at $\sim 1 / 20$ for the $0.95 \mathrm{Ca}$ alloy and $\sim 1 / 100$ for the $1.72 \mathrm{Ca}$ alloy, respectively. 


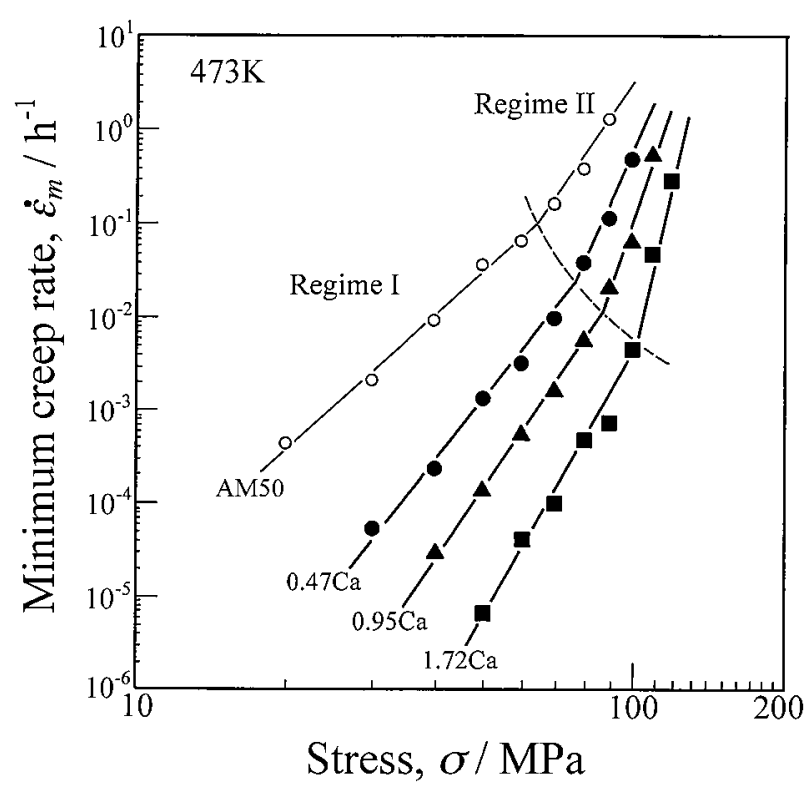

Fig. 3 Plots of minimum creep rates against stress for the $\mathrm{AM} 50+x \mathrm{Ca}$ die-cast alloys at $473 \mathrm{~K}$.

\subsection{Creep parameters of AM50 $+x$ Ca die-cast alloys}

Minimum creep rates for the AM50 $+x \mathrm{Ca}(x=0.47,0.95$ and 1.72 mass pet) alloys at $473 \mathrm{~K}$ are summarized as a function of stress in Fig. 3, accompanied by the results for the AM50 alloy. ${ }^{14,37,42)}$ Two distinct creep regimes, the low and high stress-exponent regimes, are observed for each alloy. Hereafter, the low and high stress-exponent regimes are designated as Regime I and Regime II, respectively. The critical stress of Regime I and Regime II is $65 \mathrm{MPa}$ for the AM50 alloy. With increasing calcium concentration the critical stress increases continuously to the value of $100 \mathrm{MPa}$ for the $1.72 \mathrm{Ca}$ alloy.

The critical stress of the two regimes has been identified to agree with the yield stress for the AM50 alloy. ${ }^{14)}$ It is deduced from Fig. 3 that the yield stress for the AM50 alloy increases by the addition of calcium. Note that the increase in yield stress by calcium addition has been demonstrated also for the other die-cast magnesium alloys. ${ }^{19,21,22)}$ The increase in the $n$ value at the yield stress for the AM50 $+x$ Ca alloys is probably due to the introduction of many dislocations by the instantaneous plastic strain at the stress application of creep tests in Regime II. The introduced dislocations could activate creep deformation and cause higher creep rates. The number of the introduced dislocations would be higher as the stress level is increased, resulting in the higher value of $n$ in Regime II compared with the stress exponent in Regime I.

The stress exponent of the minimum creep rate, $n$, is obtained from the slope of each line in Fig. 3 and is summarized against calcium concentration for Regime I and Regime II in Fig. 4. The value of $n$ increases from 4.6 to 10 in Regime I and from 9.2 to 31 in Regime II, when the calcium concentration is raised from 0 to 1.72 mass pct. The increase in $n$ value with calcium concentration indicates that the creep strengthening, i.e., the reduction of the minimum creep rate, by calcium addition is emphasized at lower stresses. It is found in Fig. 3 that the minimum creep rate is reduced to about $1 / 20$ at $60 \mathrm{MPa}$ by the addition of

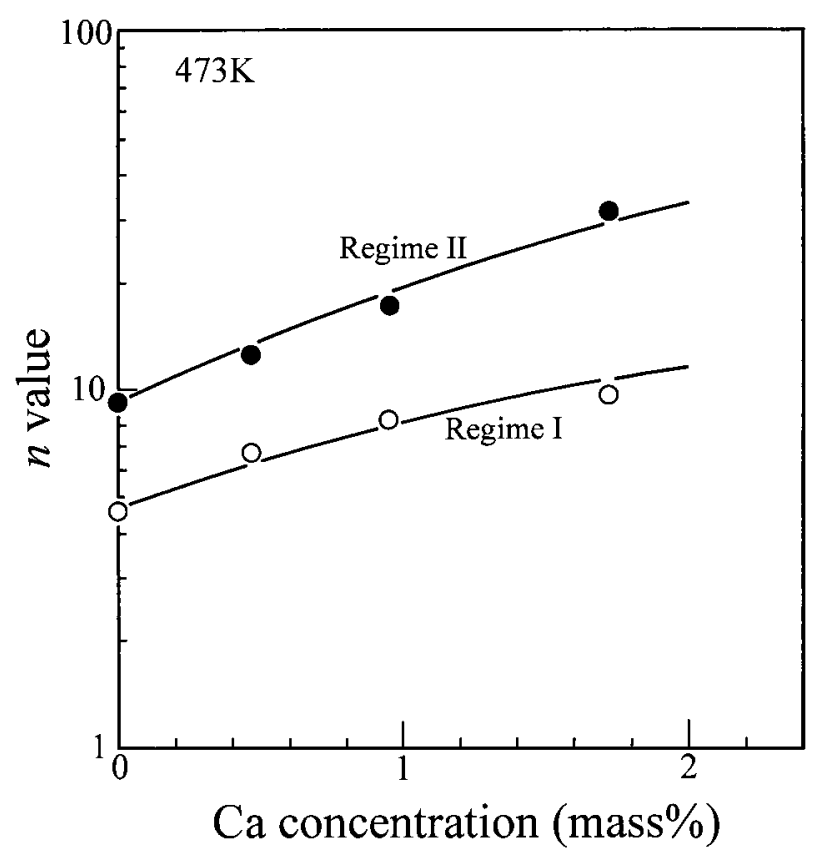

Fig. 4 Plots of $n$ value against calcium concentration for the AM50 $+x \mathrm{Ca}$ die-cast alloys at $473 \mathrm{~K}$.

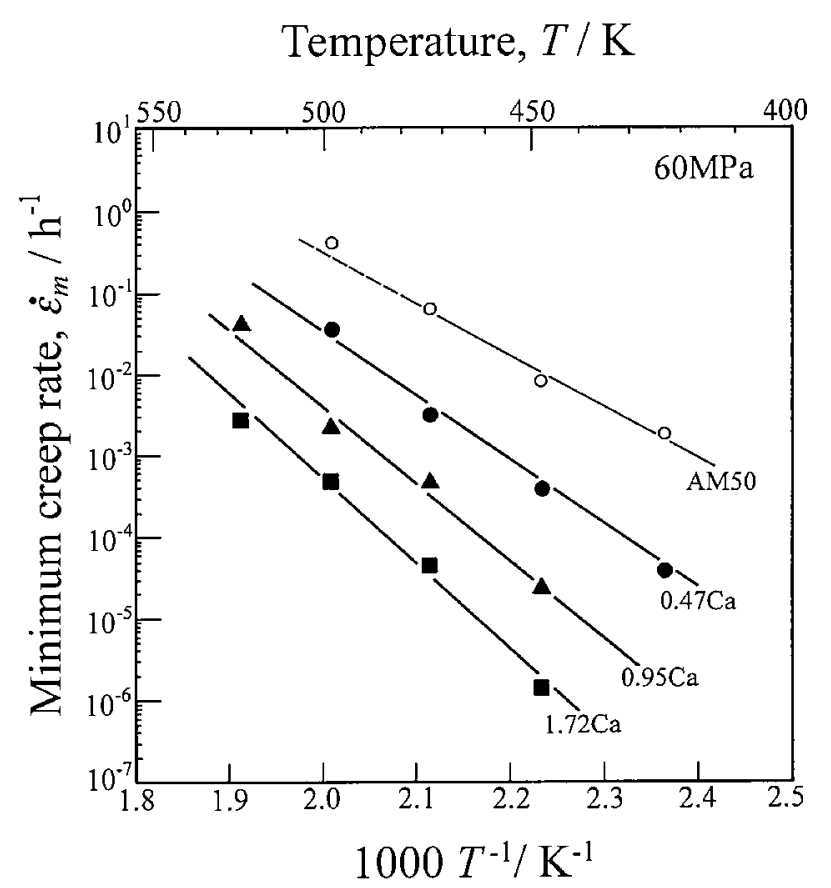

Fig. 5 Plots of minimum creep rates against $1 / T$ for the $\mathrm{AM} 50+x \mathrm{Ca}$ die-cast alloys at $60 \mathrm{MPa}$.

0.47 mass pet of calcium to the AM50 alloy. On the contrary, the reduction ratio is pronounced at $\sim 1 / 40$ at $40 \mathrm{MPa}$ and $\sim 1 / 60$ at $30 \mathrm{MPa}$, respectively.

The dependence of the minimum creep rate on the reciprocal absolute temperature is presented at the stress of $60 \mathrm{MPa}$ in Fig. 5. The stress of $60 \mathrm{MPa}$ belongs to Regime I for the calcium added alloys in the temperatures between 423 and $523 \mathrm{~K}$, while it is classified into Regime II for the AM50 alloy above $480 \mathrm{~K} .{ }^{14)}$ It is found that the decrease in the minimum creep rate by the addition of calcium is emphasized 


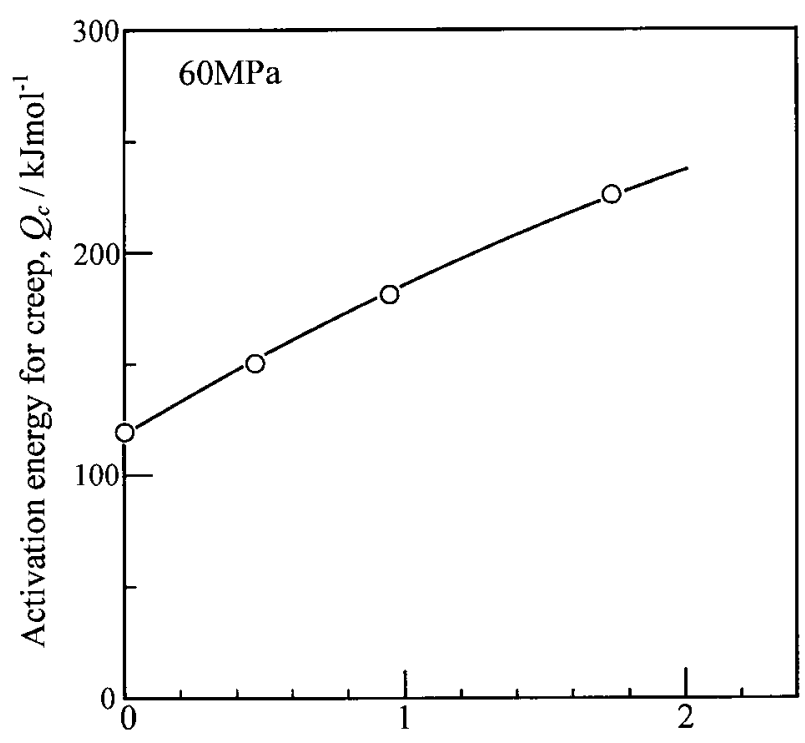

Ca concentration (mass $\%$ )

Fig. 6 Plots of $Q_{\mathrm{c}}$ values against calcium concentration for the AM50 + $x \mathrm{Ca}$ die-cast alloys at $60 \mathrm{MPa}$.

at lower temperatures. By the addition of 0.47 mass pct of calcium to the AM50 alloy, the creep rate is reduced to about $1 / 15$ at $473 \mathrm{~K}$. On the contrary, the reduction ratio is pronounced at $\sim 1 / 20$ at $448 \mathrm{~K}$ and $\sim 1 / 35$ at $423 \mathrm{~K}$, respectively.

The activation energy for creep, $Q_{\mathrm{c}}$, determined from each slope of the Arrhenius plots is shown as a function of calcium concentration in Fig. 6 . The value of $Q_{\mathrm{c}}$ shows a positive dependence on the calcium concentration, i.e., the $Q_{\mathrm{c}}$ value increases from $119 \mathrm{~kJ} / \mathrm{mol}$ for the AM50 alloy to $225 \mathrm{~kJ} / \mathrm{mol}$ for the $1.72 \mathrm{Ca}$ alloy. The value $Q_{\mathrm{c}}=119 \mathrm{~kJ} / \mathrm{mol}$ for the AM50 alloy is close to the activation energy for the lattice self-diffusion of magnesium, $Q_{1}\left(136 \mathrm{~kJ} / \mathrm{mol}^{43,44)}\right)$. On the contrary, the values of $Q_{\mathrm{c}}$ for the $0.95 \mathrm{Ca}$ and $1.72 \mathrm{Ca}$ alloys are apparently larger than that of $Q_{1}$. It is well established that the activation energies for creep in the heat resistant magnesium alloys including several alloying elements are usually much higher than that for the lattice self-diffusion of magnesium, $Q_{1}$, or that for the interdiffusion in $\mathrm{Mg}$-Al solid solution alloys, $Q_{\mathrm{int}}\left(143 \mathrm{~kJ} / \mathrm{mol}^{45)}\right)$, even in the case that dislocation creep takes place in the alloys. ${ }^{46,47)}$

\subsection{Creep strengthening by the addition of calcium}

The decrease in creep rate during transient stage becomes pronounced with increasing calcium concentration for the $\mathrm{AM} 50+x \mathrm{Ca}$ die-cast alloys (Fig. 2). The creep strengthening by the addition of calcium is emphasized at lower stresses and lower temperatures, resulting in the positive dependence of creep parameters, $n$ and $Q_{\mathrm{c}}$, against calcium concentration. The value of $n$ at $473 \mathrm{~K}$ increases from 4.6 to 10 in Regime I and from 9.2 to 31 in Regime II (Fig. 4) and the $Q_{\mathrm{c}}$ value at $60 \mathrm{MPa}$ increases from 119 to $225 \mathrm{~kJ} / \mathrm{mol}$ (Fig. 6), when the calcium concentration is raised from 0 to 1.72 mass pct.

The effect of calcium additions on creep parameters has been investigated for the ZA85 (Mg-8.0\% Zn-4.8\% Al, in mass pct) die-cast alloy at temperatures between 423 and

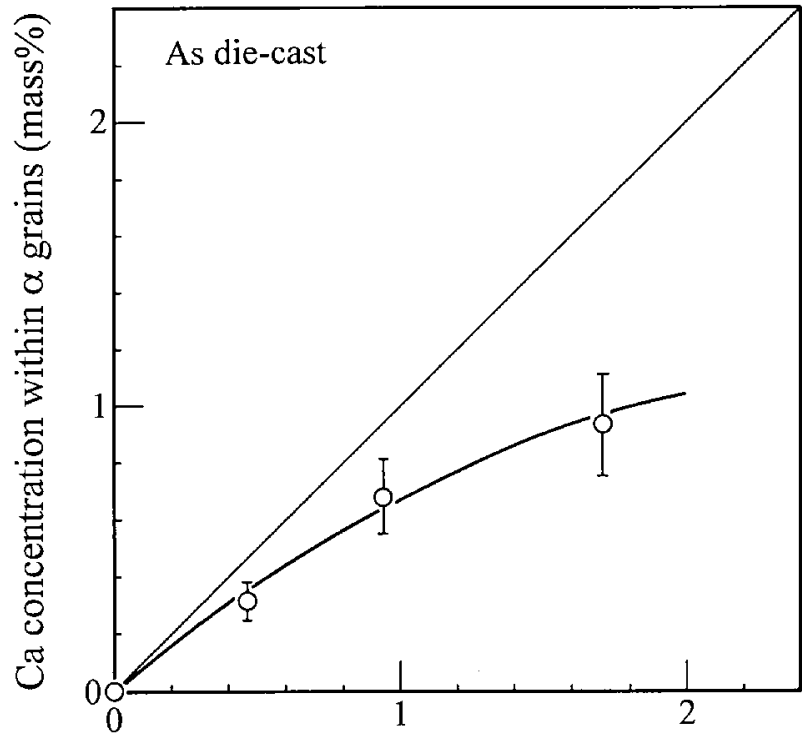

Ca concentration (mass $\%$ )

Fig. 7 Plots of calcium concentration within $\alpha$ grains obtained by SEM/ EDS analysis for the AM50 $+x$ Ca die-cast alloys.

$473 \mathrm{~K}$ through the compressive creep tests by Vogel et al. ${ }^{22)}$ They presented that the creep parameters, $n$ and $Q_{\mathrm{c}}$, remain unchanged at 6.5 and $180 \mathrm{~kJ} / \mathrm{mol}$ irrespective of the additive concentration of calcium. It is mentioned that the microstructures for the die-cast ZA85 $+x \mathrm{Ca}(0 \leqq x \leqq 0.88$, in mass pct) alloys are very similar irrespective of calcium concentration and consist of dendritic $\alpha-\mathrm{Mg}$ grains and coarse intermetallic grain boundary phases with granular in shape. ${ }^{48)}$ The positive dependence of $n$ and $Q_{\mathrm{c}}$ against calcium concentration detected for the AM50 $+x \mathrm{Ca}$ alloys in this study would be ascribed to the eutectic intermetallic phase covering the primary $\alpha$ grains, where the grain boundary coverage of $\alpha$ grains by the eutectic intermetallic phase increases continuously with the additive concentration of calcium. ${ }^{35)}$

The calcium concentration within the primary $\alpha$ grains for the die-cast AM50 $+x$ Ca specimens obtained by SEM/EDS is summarized for each alloy in Fig. 7. A part of the added calcium forms a solid solution with $\alpha$ matrix, and the other would constitute the eutectic intermetallic phase covering the $\alpha$ grains. It is noted that the eutectic intermetallic phase detected in the die-cast $\mathrm{Mg}$-Al-Ca alloys is identified as $\mathrm{C} 15-\mathrm{Al}_{2} \mathrm{Ca}$ phase in the equilibrium state. ${ }^{33,49,50)}$ The solute concentration of calcium within $\alpha$ grains increases continuously with the additive concentration of calcium for the AM50 $+x$ Ca alloys. The $3 / 4$ of the added calcium substitutes in the $\alpha$ matrix for the $0.47 \mathrm{Ca}$ alloy, while the substitution ratio of calcium decreases to about $1 / 2$ for the $1.72 \mathrm{Ca}$ alloy.

The dislocation substructure of the AM50 $+x \mathrm{Ca}$ alloys evolves during high temperature creep. The TEM micrographs of the $1.72 \mathrm{Ca}$ alloy as die-cast and creep interrupted at the minimum creep rate stage at $473 \mathrm{~K}-60 \mathrm{MPa}$ are shown in Figs. 8(a) and (b), respectively. It is noted that the incident beam direction in the TEM observation is perpendicular to the basal plane; $\mathbf{B}=[0001]$. Many dislocations are intro- 

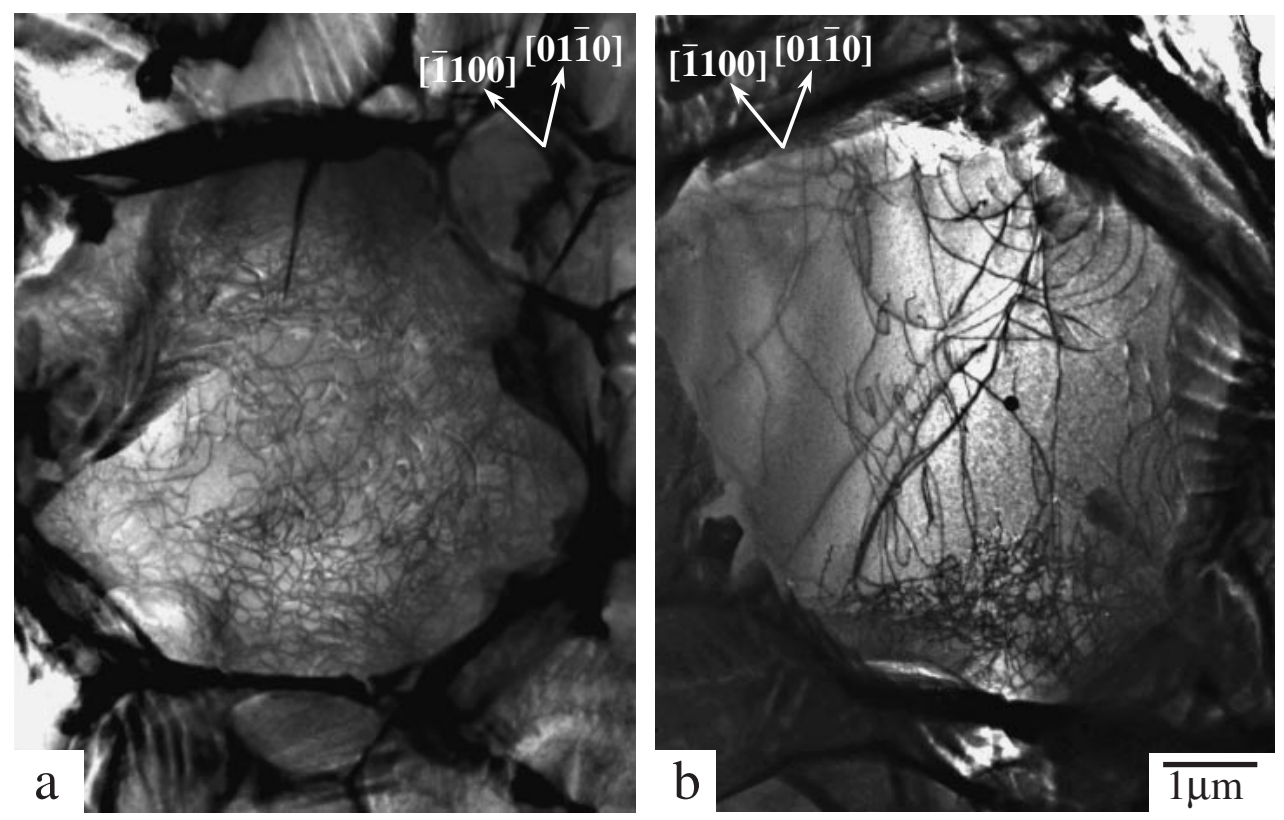

Fig. 8 Transmission electron micrographs for the AM50 + 1.72 mass $\%$ Ca die-cast alloy as die-cast (a) and creep-interrupted at the minimum creep rate stage at $473 \mathrm{~K}-60 \mathrm{MPa}(\mathrm{b})$. The beam incidence is [0001].

duced within $\alpha$ grains during the die-cast process, and the distribution of dislocations is found to be homogeneous with the density of $2 \times 10^{13} \mathrm{~m}^{-2}$ in as die-cast specimen (Fig. 8(a)). However, the dislocations concentrate to one side of the grain in the course of creep deformation, resulting in the inhomogeneous distribution of dislocations at the minimum creep rate stage (Fig. 8(b)). It appears that the eutectic intermetallic phase covering the primary $\alpha$ grains in the $\mathrm{AM} 50+x \mathrm{Ca}$ alloys prevents the dislocation annihilation at grain boundaries.

It has been demonstrated for the die-cast AXJ530 (Mg-5.1Al-2.6Ca-0.14Sr, in mass pct) alloy that the intragranular precipitation of fine $\mathrm{Al}_{2} \mathrm{Ca}$ phase exhibits during isothermal aging above $423 \mathrm{~K} .^{51)}$ However, in this study intra-granular precipitates cannot be detected for the $1.72 \mathrm{Ca}$ alloy specimen creep interrupted at the minimum creep rate stage at $473 \mathrm{~K}-60 \mathrm{MPa}$, as presented in Fig. 8(b). The primary $\alpha$ grains in the $1.72 \mathrm{Ca}$ alloy produced by die-casting would not be supersatulated with calcium, while the solubility limit of calcium into $\alpha$ matrix is quite small according to the recent binary phase diagram of $\mathrm{Mg}-\mathrm{Ca}$ system. ${ }^{52}$

In the AM50 $+x$ Ca alloys, the annihilation of dislocations would be possible only at the grain boundaries free from the eutectic intermetallic phase. The addition of calcium to the AM50 alloy retards the dislocation annihilation due to the increase in grain boundary coverage of $\alpha$ grains by the eutectic intermetallic phase, ${ }^{35)}$ which enlarges the transient creep stage for the AM50 $+x \mathrm{Ca}$ alloys with higher calcium concentration as presented in Fig. 2. The rate of dislocation annihilation would reduce at lower temperatures because of the decreased diffusivity of vacancies, resulting in the increased creep strengthening by the addition of calcium at lower temperatures (Fig. 5). The dislocations are hard to concentrate in the vicinity of grain boundaries free from the eutectic intermetallic phase at lower stresses, which results in the increased creep strengthening by calcium addition at lower stresses (Fig. 3). In conclusion, the creep strengthening by the addition of calcium for the AM50 die-cast alloy results from both the solid solution strengthening of the $\alpha$ matrix by solute calcium and the retardation of dislocation annihilation attributed to the eutectic imtermetallic phase covering $\alpha$ grains.

\section{Conclusions}

Tensile creep tests were carried out for the AM50 $+x \mathrm{Ca}$ ( $x=0.47,0.95$ and 1.72) die-cast alloys at temperatures between 423 and $523 \mathrm{~K}$ to elucidate the effect of calcium additions on creep properties for the AM50 alloy. The obtained results are summarized as follows:

(1) The creep curve for the alloys is characterized by a minimum in the creep rate followed by an extended accelerating stage. The decrease in creep rate during the transient stage becomes pronounced with increasing calcium concentration. The creep strengthening, i.e., the reduction of the minimum creep rate, by the addition of calcium is emphasized at lower stresses and lower temperatures, resulting in the positive dependence of creep parameters, $n$ and $Q_{\mathrm{c}}$, against calcium concentration for the AM50 $+x$ Ca alloys.

(2) Many dislocations are introduced within $\alpha$ grains during the die-cast process. The distribution of dislocations turns from homogeneous to inhomogeneous in the course of creep deformation. The eutectic intermetallic phase covering the primary $\alpha$ grains prevents the dislocation annihilation at grain boundaries. The creep strengthening by the addition of calcium results from both the solid solution strengthening of the $\alpha$ matrix by solute calcium and the retardation of dislocation annihilation attributed to the eutectic imtermetallic phase. 


\section{Acknowledgments}

The authors acknowledge Mitsubishi Aluminum Co. for providing die-cast alloy specimens. This work is supported by the Grant-in-Aid for Scientific Research C (19560698) of JSPS, Japan. One of the authors (Y. Terada) greatly appreciates the support from Research Foundation for Materials Science.

\section{REFERENCES}

1) B. L. Mordike and T. Ebert: Mater. Sci. Eng. A 302 (2001) 37-45.

2) S. Das: JOM 55 (2003) 22-26.

3) N. Hort, Y. Huang and K. U. Kainer: Adv. Eng. Mater. 8 (2006) 235240.

4) T. Kaneko and M. Suzuki: Mater. Sci. Forum 419-422 (2003) 67-72.

5) E. Aghion, B. Bronfin, F. V. Buch, S. Schumann and H. Friedrich: JOM 55 (2003) 30-33.

6) M. O. Pekguleryuz and A. A. Kaya: Adv. Eng. Mater. 5 (2003) 866878.

7) K. Maruyama, M. Suzuki and H. Sato: Metall. Mater. Trans. A 33A (2002) 875-882.

8) V. Sklenicka, M. Pahutova, K. Kucharova, M. Svoboda and T. G. Langdon: Metall. Mater. Trans. A 33A (2002) 883-889.

9) K. Hirai, H. Somekawa, Y. Takigawa and K. Higashi: Mater. Sci. Eng. A 403 (2005) 276-280.

10) S. M. Zhu, B. L. Mordike and J. F. Nie: Metall. Mater. Trans. A 37A (2006) 1221-1229.

11) Y. Terada, N. Ishimatsu and T. Sato: Mater. Trans. 48 (2007) 23292335.

12) R. L. Edgar: Magnesium Alloys and their Applications, ed. by K. U. Kainer (Wiley-VCH, Weinheim, 2000) pp. 3-8.

13) P. Bakke and H. Westengen: Adv. Eng. Mater. 5 (2003) 879-885.

14) N. Ishimatsu, Y. Terada, T. Sato and K. Ohori: Metall. Mater. Trans. A 37A (2006) 243-248.

15) A. A. Luo, M. P. Balogh and B. R. Powell: Metall. Mater. Trans. A 33A (2002) 567-574.

16) E. Evangelista, S. Spigarelli, M. Cabibbo, C. Scalabroni, O. Lohne and P. Ulseth: Mater. Sci. Eng. A 410-411 (2005) 62-66.

17) S. Spigarelli, E. Evangelista, M. Cabibbo, O. Lohne and P. Ulseth: Z. Metallkd. 96 (2005) 619-624.

18) A. Suzuki, N. D. Saddock, J. W. Jones and T. M. Pollock: Magnesium Technology 2005, ed. by N. R. Neelameggham, H. I. Kaplan and B. R. Powell (TMS, Warrendale, 2005) pp. 111-116.

19) T. Horie, H. Iwahori, Y. Seno and Y. Awano: Magnesium Technology 2000, ed. by H. I. Kaplan, J. Hryn and B. Clow (TMS, Warrendale, 2000) pp. 261-269.

20) Y. Terada, R. Sota, N. Ishimatsu, T. Sato and K. Ohori: Metall. Mater. Trans. A 35A (2004) 3029-3032.

21) Z. Zhang, R. Tremblay and D. Dube: Mater. Sci. Eng. A 385 (2004) 286-291.

22) M. Vogel, O. Kraft and E. Arzt: Metall. Mater. Trans. A 36A (2005) 1713-1719.

23) H. Gjestland, G. Nussbaum, G. Regazzoni, O. Lohne and O. Bauger: Mater. Sci. Eng. A 134 (1991) 1197-1200.

24) M. Suzuki, J. Koike, K. Maruyama, T. Tsukeda, K. Saito and H. Kubo:
Magnesium Alloys and their Applications, ed. by K. U. Kainer (WileyVCH, Weinheim, 2000) pp. 699-704.

25) T. Tsukeda, A. Maehara, K. Saito, M. Suzuki, J. Koike, K. Maruyama and H. Kubo: Magnesium Technology 2000, ed. by H. I. Kaplan, J. Hryn and B. Clow (TMS, Warrendale, 2000) pp. 395-402.

26) C. Mendis, L. Bourgeois, B. Muddle and J. F. Nie: Magnesium Technology 2003, ed. by H. I. Kaplan (TMS, Warrendale, 2003) pp. 183-188.

27) M. Liu, Q. Wang, X. Zeng, G. Yuan, Y. Zhu and W. Ding: Mater. Sci. Forum 488-489 (2005) 763-766.

28) J. Grobner, D. Kevorkov, I. Chumak and R. Schmid-Fetzer: Z. Metallkd. 94 (2003) 976-982.

29) A. Suzuki, N. D. Saddock, J. W. Jones and T. M. Pollock: Metall. Mater. Trans. A 37A (2006) 975-983.

30) A. Suzuki, N. D. Saddock, J. W. Jones and T. M. Pollock: Acta Mater. 53 (2005) 2823-2834.

31) R. M. Wang, A. Eliezer and E. M. Gutman: Mater. Sci. Eng. A 355 (2003) 201-207.

32) M. O. Pekguleryuz and J. Renaud: Magnesium Technology 2000, ed. by H. I. Kaplan, J. Hryn and B. Clow (TMS, Warrendale, 2000) pp. 279284.

33) K. Ozturk, Z. K. Liu and A. A. Luo: Magnesium Technology 2003, ed. by H. I. Kaplan (TMS, Warrendale, 2003) pp. 195-200.

34) R. Ninomiya, T. Ojiro and K. Kubota: Acta Metall. Mater. 43 (1995) 669-674.

35) D. Itoh: Master Thesis, Tokyo Institute of Technology, Tokyo, 2007.

36) Y. Mori, Y. Terada and T. Sato: Mater. Trans. 46 (2005) 1749-1752.

37) Y. Terada and T. Sato: Mater. Trans. 49 (2008) 439-442.

38) W. Blum, P. Weidinger, B. Watzinger, R. Sedlacek, R. Rosch and H. G. Haldenwanger: Z. Metallkd. 88 (1997) 636-641.

39) M. Regev, E. Aghion and A. Rosen: Mater. Sci. Eng. A 234-236 (1997) $123-126$.

40) M. Regev, O. Botstein, M. Bamberger and A. Rosen: Mater. Sci. Eng. A 302 (2001) 51-55.

41) S. M. Zhu, B. L. Mordike and J. F. Nie: Magnesium Technology 2005, ed. by N. R. Neelameggham, H. I. Kaplan and B. R. Powell (TMS, Warrendale, 2005) pp. 429-434.

42) Y. Terada, Y. Mori and T. Sato: Mater. Trans. 47 (2006) 2493-2496.

43) P. G. Shewmon and F. N. Rhines: Trans. AIME 200 (1954) 1021-1025.

44) P. G. Shewmon: Trans. AIME 206 (1956) 918-922.

45) G. Moreau, J. A. Cornet and D. Calais: J. Nucl. Mater. 38 (1971) 197202.

46) J. Cadek, V. Sustek, L. Kloc and E. Evangelista: Mater. Sci. Eng. A 215 (1996) 73-83.

47) J. G. Wang, L. M. Hsiung, T. G. Nieh and M. Mabuchi: Mater. Sci. Eng. A 315 (2001) 81-88.

48) M. Vogel, O. Kraft, P. Staron, H. Clemens, R. Rauh and E. Arzt: Z. Metallkd. 94 (2003) 564-571.

49) A. Suzuki, N. D. Saddock, J. W. Jones and T. M. Pollock: Scr. Mater. 51 (2004) 1005-1010.

50) Y. Terada, N. Ishimatsu, Y. Mori and T. Sato: Mater. Trans. 46 (2005) 145-147.

51) A. Suzuki, N. D. Saddock, J. R. TerBush, B. R. Powell, J. W. Jones and T. M. Pollock: Magnesium Technology 2007, ed. by R. S. Beals, A. A. Luo, N. R. Neelameggham and M. O. Pekguleryuz (TMS, Warrendale, 2007) pp. 375-380.

52) T. B. Massalski: Binary Alloy Phase Diagrams, 2nd edn., (ASM International, Materials Park, 1990). 